\section{Small steps forward}

\section{The presidency of Olusegun Obasanjo, whatever its pitfalls, has been positive for Nigerian science.}

T he orderly transfer of power is an important test of any democracy. This Saturday, voters will go to the polls in Nigeria to select a successor to President Olusegun Obasanjo, the former general elected in 1999. Having served two terms, Obasanjo will return to academic life. But the election campaign has already been characterized by considerable violence, and it remains to be seen if its outcome can be regarded as fair.

Over the course of his presidency, Obasanjo has emerged as one of the most significant figures in contemporary African politics and has attempted to incorporate science into the continent's development. In recent months, he has given the go-ahead for reforms to Nigeria's science and technology governance, which had stagnated since independence in 1960. The reforms include creating a new National Council for Research and Development (to be chaired by his successor), and a number of individual research councils, which will provide funding on a competitive basis for research in specific areas such as agriculture and energy, as well as provision for independent quality assessments in the universities.

New research centres have also been established, including the African Institute for Science and Technology in Abuja. But perhaps his most ambitious plan was that of a major expansion, announced in June 2006, of the country's Petroleum Technology Development Fund, to set aside US $\$ 5$ billion of oil revenues for research grants, education and infrastructure. The fund has been in existence for years, but the expansion could go some way towards protecting Nigerian researchers from the inevitable budget cuts that take place in oil-dependent nations when oil prices fall, or if political priorities change.

Unfortunately, the petroleum fund is now at the heart of a dispute between the departing president and the vice-president, Atiku Abubakar, who is standing for the presidency this time round. Each has accused the other of diverting money from the fund to nonscientific causes (see www.scidev.net/News/index.cfm?fuseaction= readNews\&itemid=3334). So the jury remains out on whether the fund is ever going to materialize in its advertised form.

All of Nigeria's main opposition parties seem to be signed up to the Obasanjo agenda for science and development. The next president will inherit a range of instruments for promoting education and science - as well as a massive challenge in addressing poverty, disease and corruption. According to the United Nations Development Programme, one in two Nigerians lacks access to clean water, and life expectancy is less than 44, unmoved since 1970.

But at least Obasanjo recognized that Nigeria needs to invest in education and research in order to confront these challenges - an approach that is growing more popular across sub-Saharan Africa. That has provided a platform on which his successor can build.

\section{Addicted to secrecy}

\section{Sealed drug documents should be opened up.}

n the course of lengthy, expensive litigation over drug safety in the United States, opposing sets of lawyers often form unholy alliances. These cases are frequently settled before reaching court, and the two sides agree to confidentiality orders being placed on any drug-company documents to which they have been granted access. This suits the courts, which want parties to cases under their jurisdiction to gain access to as much information as possible; the drug companies, who want to keep most of the data confidential; and the plaintiffs' lawyers, who want to win a good deal for their clients. But it may not suit the wider public interest.

Every now and then, some of those sealed documents leak out. In a recent trial concerning the schizophrenia drug Zyprexa, for example, documents emerged that suggested to some parties that the manufacturer, Eli Lilly, had sought to play down some known side-effects of the drug (see page 838). But documents considered during pre-trial negotiations usually remain sealed by private agreement between the court and both sets of attorneys - even where there is a public-health interest in releasing some of the information they contain.

Some plaintiffs' attorneys have argued for the creation of ethical guidelines or legislation that would bar lawyers from reaching such agreements. Drug companies have countered that the agreements are helpful to the fair resolution of cases because they allow fairly untrammelled access to information relevant to each case. Without such agreements, defendants would doubtless resist the release of both personal and commercially sensitive information, slowing down cases and reducing their chances of just resolution.

Even so, a few states, such as Florida, have introduced anti-secrecy laws. But there are also other reform options. Courts could, for example, be allowed to take previous secrecy orders into consideration when setting damages. Drug companies might think twice about sealing data from clinical trials if they knew they could come out in a future trial and incur greater financial cost.

Scientific bodies have an interest in ensuring that as many public-health data as possible are released into the public domain. The Institute of Medicine and the American Association for "Scientific bodies have an interest in ensuring that public-health data are released into the public domain."

the Advancement of Science (which already has a joint committee with the American Bar Association to consider such matters) could help by fostering discussions between the plaintiffs' lawyers and the drug industry on how to move the issue forward.

The industry's reputation, as well as the public good, will benefit in the long run from arrangements that get pertinent information about drug safety into the public domain as quickly as possible. Global registers of clinical-trial results are probably the most pressing requirement here. But less court-imposed secrecy around public health would also be a positive step, in part by helping to ensure that companies are fully complying with such registers. 